Abstracta Iranica Abstracta Iranica

Revue bibliographique pour le domaine irano-aryen

Volume 34-35-36 | 2017

Comptes rendus des publications de 2011-2013

Mehdi Rahbar. Kashf kārgāh sharāb doreh sāsāni dar Tāq-e Bostān / A Sasanid Period Wine Making

Installation at Taq-e Bostan

Rémy Boucharlat

(2) OpenEdition

Journals

Édition électronique

URL : http://journals.openedition.org/abstractairanica/41813

DOI : $10.4000 /$ abstractairanica. 41813

ISSN : 1961-960X

Éditeur :

CNRS (UMR 7528 Mondes iraniens et indiens), Éditions de l'IFRI

Référence électronique

Rémy Boucharlat, « Mehdi Rahbar. Kashf kārgāh sharāb doreh sāsāni dar Tāq-e Bostān / A Sasanid Period Wine Making Installation at Taq-e Bostan », Abstracta Iranica [En ligne], Volume 34-35-36 | 2017,

document 23, mis en ligne le 30 décembre 2016, consulté le 27 septembre 2020. URL : http://

journals.openedition.org/abstractairanica/41813; DOI : https://doi.org/10.4000/abstractairanica.

41813

Ce document a été généré automatiquement le 27 septembre 2020.

Tous droits réservés 


\title{
Mehdi Rahbar. Kashf kārgāh sharāb doreh sāsāni dar Tāq-e Bostān / A Sasanid Period Wine Making Installation at Taq-e Bostan
}

\author{
Rémy Boucharlat
}

\section{RÉFÉRENCE}

Mehdi Rahbar. « Kashf kārgāh sharāb doreh sāsāni dar Tāq-e Bostān / A Sasanid Period Wine Making Installation at Taq-e Bostan ». Modares Archaeological Research, 4, Nos. 8, 2011-2013, 2013, p. 153-161.

Découverte en 2009 d'une installation de pressage de raisin pour produire du vin, lors d'une fouille de sauvetage près d'une usine à Tāq-e Bostān. L'ensemble est constitué en particulier par deux bassins en briques cuites, d'inégales dimensions, communicants par des tuyaux en terre cuite. De grands vases ovoïdes à fond en bouton devaient être fixés en terre. Daté de l'époque sassanide (e.g. un bol en verre taillé à facettes), cet ensemble est comparable à une installation fouillée en 2005-2006 dans le Tang-i Bolaghi, près de Pasargades, la première évidence d'une telle activité en Iran (B. Kaim, A. Asadi, R. Heydari, in Archaeological Reports 7, 2, 2007, p. 71-96). L'A. indique que des découvertes semblables ont été faites à Bandian dans le Hुorāsān et près de Fīrūzābād. 


\section{AUTEURS}

RÉMY BOUCHARLAT

CNRS, Lyon 